\title{
A rare clinical presentation of Desmoplastic Trichilemmoma mimicking Invasive Carcinoma*
}

\author{
Daniela Tiemi Sano ${ }^{1}$ \\ Antonio José Tebcherani ${ }^{1}$
}

\author{
Jeane Jeong Hoon Yang ${ }^{1}$ \\ Luiz Arthur de Paula Machado Bazzo
}

DOI: $h$ ttp://dx.doi.org/10.1590/abd1806-4841.20143095

\begin{abstract}
Trichilemmoma is a benign neoplasm from the outer sheath of the pilosebaceous follicle. Desmoplastic trichilemmoma, a rare variant, is histologically characterized by a central area of desmoplasia that can clinically mimic an invasive carcinoma, requiring histopathological examination to define the diagnosis.
\end{abstract}

Keywords: Hair diseases; Hair follicle; Skin neoplasms

\section{INTRODUCTION}

The trichilemmoma is a benign solid tumor originating from external sheath cells of pilosebaceous follicles, and the desmoplastic trichilemmoma is a rare benign histological variant. ${ }^{1,2,3}$ Clinically, it may look like other cutaneous lesions. ${ }^{2}$ Among the differential diagnoses, we can cite basal-cell carcinoma, squamous cell carcinoma and viral lesions; the histopathological examination is necessary for diagnostic confirmation. We report here a case of desmoplastic trichilemmoma in a rare clinical presentation, simulating an invasive carcinoma. ${ }^{3}$

\section{CASE REPORT}

Male patient, 78 years old, white, mentioned onset of a lesion in the right retroauricular region for 4 years, with progressive increase, associated with the presence of central ulceration and local bleeding. He denied pain and association with other signs and systemic symptoms. Previously hypertensive and diabetic, with a history of cerebrovascular accident 1 year ago. Ex-smoker for 40 years. He denied alcoholism. He denied similar cases in relatives. He mentioned a trauma next to the lesion site approximately 50 years ago, unrelated with the onset of current lesion. At the dermatological examination, he presented erythematous tumor with shiny borders and central ulceration, measuring approximately $2 \mathrm{~cm}$ along the largest diameter in the right retroauricular region (Figures 1 and 2). Diagnostic hypotheses were produced for basalcell carcinoma, squamous-cell carcinoma and keratoacanthoma. It was opted to remove the lesion by surgery. The anatomopathological examination was compatible with the diagnosis of desmoplastic trichilemmo- ma, without the presence of malignant processes, and associated with nevus sebaceous of Jadassohn in the periphery of the lesion (Figures 3, 4, 5 and 6). Patient is still under outpatient follow-up, with good clinical evolution and no relapse of lesion.

\section{DISCUSSION}

The trichilemmoma is a benign tumor originating from external root sheath cells of pilosebaceous follicles, described for the first time by Headington and French in 1962. In 1990, Hunt and colleagues described a clinical variant of the neoplasm, the desmoplastic trichilemmoma, characterized by a central zone of desmoplasia, which can clinically simulate an invasive carcinoma. ${ }^{1,2,3}$

The desmoplastic trichilemmoma is a rare trichilemmoma variant and is predominant in women, usually after the fifth decade of life..$^{1,4}$ A tumor suppressor gene named PTEN/MMAC1 has been reported as the causal agent. ${ }^{5}$ Some authors consider it to be a kind of viral wart based on the findings of conventional microscopic sections. However, molecular genetic studies usually do not demonstrate papilloma virus in these lesions and thus a viral cause does not seem probable., ${ }^{2,5}$

Clinically, it is characterized by a papule or nodule usually skin colored or erythematous, asymptomatic, with a dome-like appearance and a smooth or keratotic surface, frequently located on the face, possibly involving other locations such as neck, scalp, thorax and vulva. It presents a slow and progressive growth. The lesion evolution time can vary from months to years. Occasionally, it presents pearly edges and ulcera-

\footnotetext{
Received on 25.08.2013.

Approved by the Advisory Board and accepted for publication on 20.09.2013.

Work performed at Complexo Hospitalar Padre Bento de Guarulhos (CHPBG) - Guarulhos (SP), Brazil

Financial Support: none

Conflict of Interests: none

Complexo Hospitalar Padre Bento de Guarulhos (CHPBG) - Guarulhos (SP), Brazil.
} 
tion on its surface. It rarely exceeds $1 \mathrm{~cm}$ in diameter.,

The trichilemmomas are small and circumscribed lobular or multilobular proliferations composed mainly of pale cells from the external sheath containing glycogen in its interior, usually with wide connection to the epidermal surface. The clear aspect of

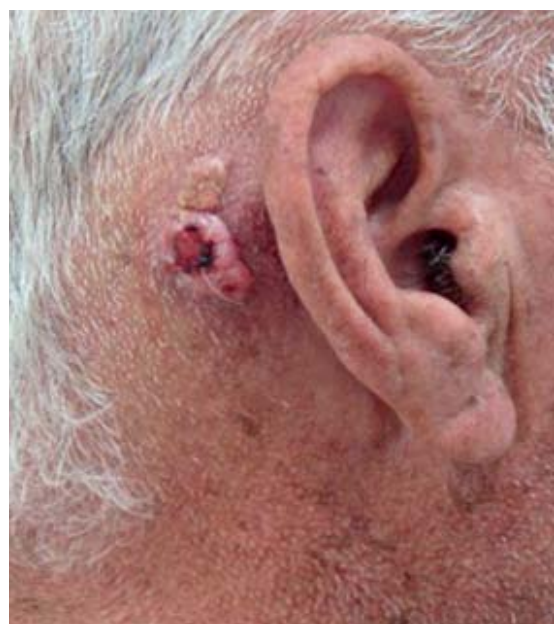

FIGURE 1:

Erythematous

growth with

shiny edges and

central ulceration,

measuring appro-

ximately $2 \mathrm{~cm}$

along its biggest

diameter in the

right retroauricu-

lar region

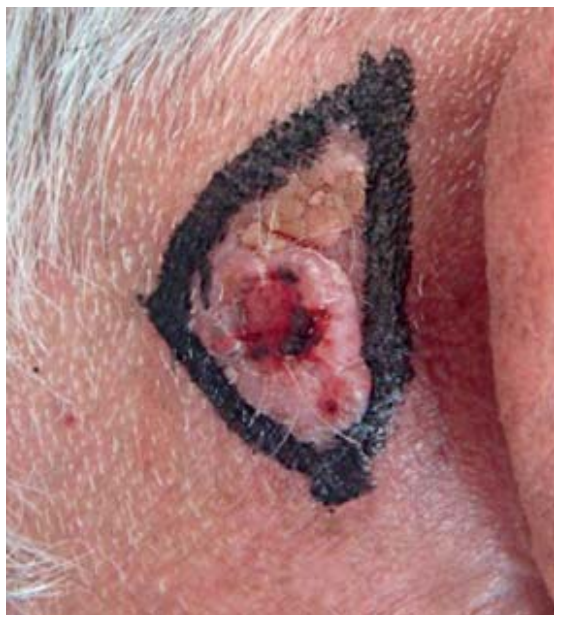

FIgURE 2: Detail of lesion in the right retroauricular region

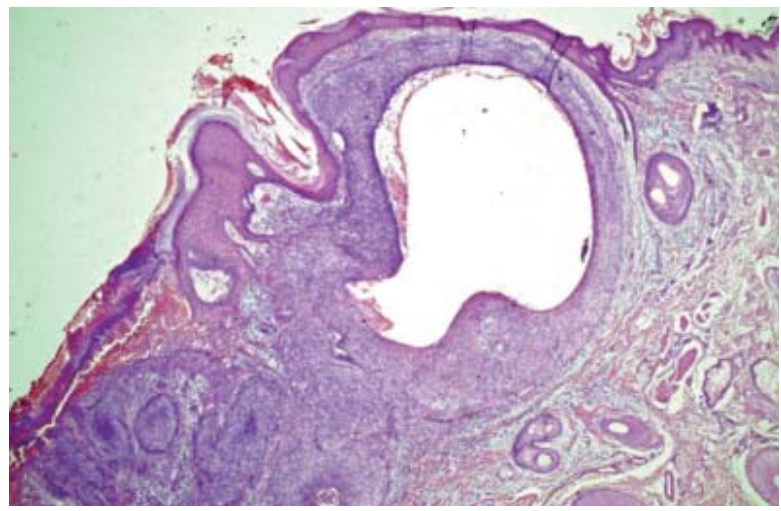

FIGURE 3: HE. 40x. Panoramic view, evidencing the connection of the lesion to a hair follicle

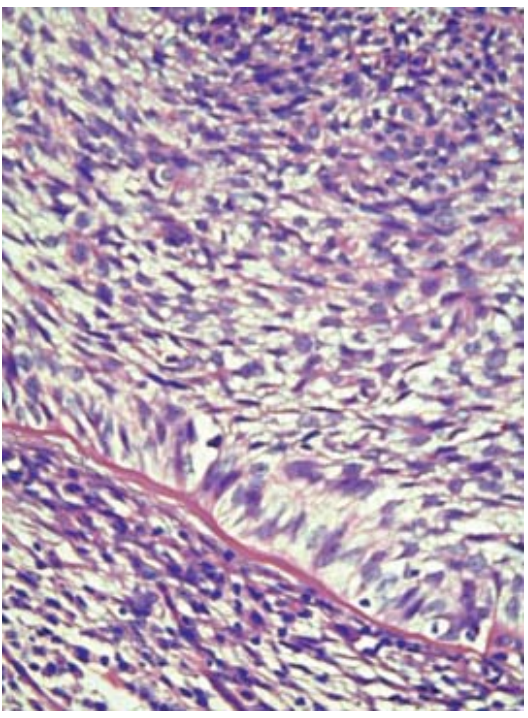

FIGURE 4:

HE 400x

Histological aspect of clear cells, with the peripheral palisade

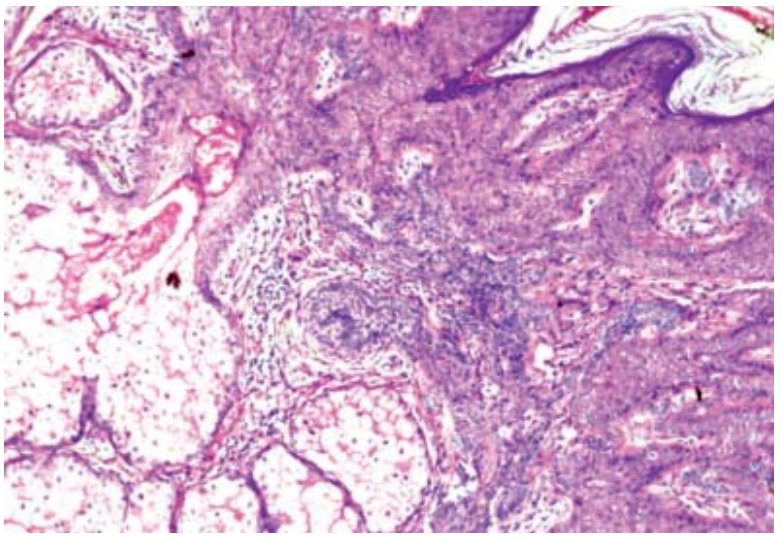

FiguRE 5: HE 40x. Adjacent epidermis with papillomatosis, sebaceous hyperplasia

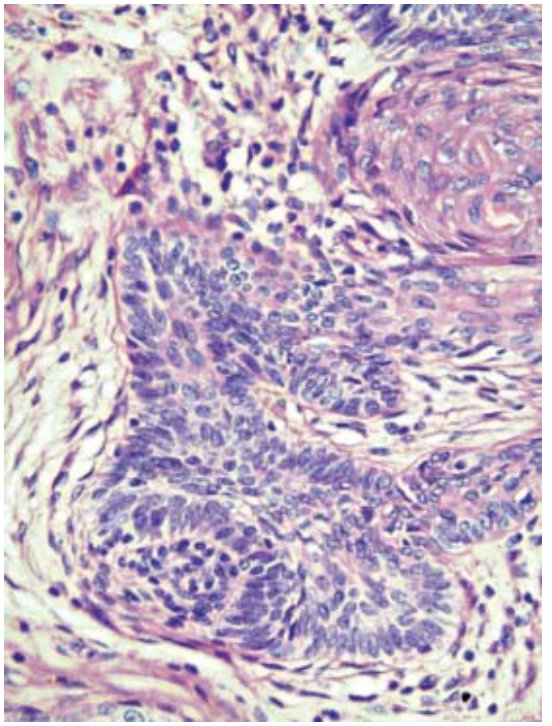

FiguRE 6: HE 400x.

Epithelial basaloid projections of epidermis, involved by fibroblasts 
cells is due to the accumulation of glycogen, which can be evidenced by the combination of PAS stains with or without diastase. A papillomatous surface is common and there may be acute verrucous hyperplasia with hypergranulosis. Squamous swirls are also common. There is a palisade of small and compact basal keratinocytes at the periphery of a lobe, usually with a thickened adjacent basal membrane and periodic acid-Schiff with positive diastase (PAS-D). In desmoplastic trichilemmoma, histology is similar to trichilemmoma with central desmoplastic stroma. ${ }^{7}$ The center is composed of irregular cords and nests of basaloid cells embedded in a dense collagenous sclerotic stroma. Usually, the lesion mimics an invasive carcinoma. However, nuclear atypia and mitotic activity are not normally present. ${ }^{2,8}$

The desmoplastic aspect of the lesion, characterized by cords of cells wrapped in fibrosis, can be observed in this case. The knowledge of this desmoplastic variant is important due to the possible confusion with basal-cell carcinoma. In this case, we also found acanthosis and pappilomatosis in the lesion periphery, in addition to sebaceous hyperplasia and small basaloid epidermal projections, configuring an associated nevus sebaceous of Jadassohn. This variant, known as desmoplastic trichilemmoma, is especially common in this context.

Cases of multiple facial trichilemmomas, with sclerotic fibromas and acrokeratosis verruciformis, may represent an important marker for the Cowden syndrome. Patients with Cowden syndrome show a tendency to develop internal malignancies, especially in the breasts, thyroid and gastrointestinal tract. It is important, in these cases, to carry out an investigation

\section{REFERENCES}

1. Schweiger E, Spann CT, Weinberg JM, Ross B. A Case of Desmoplastic Trichilemmoma of the Lip Treated with Mohs Surgery. Dermatol Surg. 2004;30:1062-4.

2. McCalmont TH. Neoplasias anexiais. In: Bolognia JL, Jorizzo JL, Rapini RP. Dermatologia. 2 ed.; traduzida. Rio de Janeiro: Elsevier; 2011. p. 1699-1700.

3. Sampaio SAP, Rivitti EA. Tumores Epiteliais Benignos. In: Sampaio SAP, Rivitti EA, editores. Dermatologia. 3 ed; 2008. p. 1151.

4. Topping NC, Chakrabarty A, Edrich C, Henderson T. Desmoplastic trichilemmoma of the upper eyelid. Eye (Lond). 1999;13:593-4.

5. Taylor RS, Perone JB, Kaddu S, Kerl H. Tumores Anexiais e Hamartomas da Pele. In: Wolff K, Goldsmith LA, Katz SI, Gilchrest BA, Paller AS, Leffell DJ, editors. Fitzpatrick Tratado de Dermatologia. 7 ed. Rio de Janeiro: Revinter Ltda; 2011. p. 1084-5.

6. Crowson AN, Magro CM. Basal cell carcinoma arising in association with desmoplastic trichilemmoma. Am J Dermatopathol. 1996;18:43-8.

7. Rapini RP. Neoplasias Foliculares. In: Rapini RP. Dermatopatologia Prática. Rio de Janeiro: Editora Dilivros; 2007. p. 290-1.

8. Afshar M, Lee RA, Jiang SI. Desmoplastic Trichilemmoma - A Report of Successful Treatment with Mohs Micrographic Surgery and a Review and Update of the Literature. Dermatol Surg. 2012;38:1867-71. of possible systemic involvement.,

Due to non-specific clinical presentations of desmoplastic trichilemmoma, it may look similar to other cutaneous lesions. Among the differential diagnoses we can cite basal-cell carcinoma, trichilemmal carcinoma, cutaneous horn, papilloma, intradermal nevus, seborrheic keratosis, sebaceous carcinoma, invasive carcinoma and squamous cell carcinoma. Histopathologic examination is required for diagnostic confirmation. ${ }^{4,8}$

Indeed, it is important to consider the histological analysis of desmoplastic trichilemmoma, for it simulates trichilemmal carcinoma, squamous-cell carcinoma and basal-cell carcinoma, with direct implication in misdiagnosed cases. ${ }^{4}$ Immunohistochemical methods can be used to differentiate the desmoplastic trichilemmoma from other tumors with follicular differentiation. ${ }^{3}$ The trichilemmoma expresses marker BCL-2 in the most peripheral portion of neoplastic cells. In this case, marker Ki67 was measured, which evidenced a low cell proliferation rate $(30 \%)$, more intense in the periphery of the lesion, which favors the profile of a benign process.

Since it is a benign neoplasia, surgical excision of desmoplastic trichilemmoma is not necessary. However, as it is a rare cutaneous neoplasm and easily mistaken for other invasive cutaneous neoplasms, a complete surgical excision is advised for histopathological examination and diagnostic definition. There are also reports of association of desmoplastic trichilemmoma with atypical basaloid proliferations, such as basal-cell carcinoma, maintaining the importance of diagnostic confirmation by histopathological analysis of the lesion. ${ }^{8,10} \square$

9. Chan P, White SW, Pierson DL, Rodman OG. Trichilemmoma. J Dermatol Surg Oncol. 1979:5:58-9.

10. Simpson W, Garner A, Collin JR. Benign hair-follicle derived tumours in the differential diagnosis of basal-cell carcinoma of the eyelids: a clinicopathological comparison. Br J Ophthalmol. 1989;73:347-53.
MAILING ADDRESS:
Daniela Tiemi Sano
Secretaria da Dermatologia.
Av. Emílio Ribas,1819.
Bairro Gopouva - Guarulhos - São Paulo - SP
07051-000
Brazil
E-mail:danitsano@yahoo.com.br

How to cite this article: Sano DT, Yang JJH, Tebcherani AJ, Bazzo LAPM. A rare clinical presentation of Desmoplastic Trichilemmoma mimicking Invasive Carcinoma. An Bras Dermatol. 2014;89(5):796-8. 